\title{
INCREASE IN SIZE OF THE PULMONARY AUTOGRAFT AFTER THE ROSS OPERATION IN CHILDREN: GROWTH OR DILATION?
}

Laszlo Solymar, MD, PhD

Göran Südow, MD

Daniel Holmgren, MD, PhD
Objective: We sought to assess growth properties of the pulmonary autograft after the Ross operation in children. Methods: Eight infants with critical aortic stenosis who underwent the Ross operation early in life (median age, 6.4 months) were followed up regarding the possible growth of the autograft. The pulmonary autograft was measured repeatedly by echocardiography during the follow-up, ranging from 6 months to 7 years (median, 5.2 years). Twelve normal children who served as control subjects were similarly followed from 3.9 to 5.8 years (median, 4.9 years). Results: Somatic growth during the follow-up period was significant and was reflected in a doubling of the body surface area, which increased from $0.33 \pm 0.14 \mathrm{~m}^{2}$ to $0.74 \pm 0.21 \mathrm{~m}^{2}$. The proximal part of the autograft increased from $13.6 \pm 3.6 \mathrm{~mm}$ to $23.3 \pm 3.7 \mathrm{~mm}$ (mean \pm SD) and the distal part from $10.5 \pm 2.5 \mathrm{~mm}$ to $15.9 \pm 2.8 \mathrm{~mm}$. Growth pattern of the autograft was analyzed by relating measured diameters to predicted normal diameters (ie, $Z$ values). During the first year after the operation, the mean $Z$ value of the proximal autograft increased from 0.2 to 2.2 , indicating a more rapid increase than the predicted increase and was also significantly higher than that of the control group $(P=.01)$. After the first year, $Z$-value changes in patients and control subjects were very similar. Conclusions: We thus conclude that the pulmonary autograft in the aortic position after the Ross operation does increase in size and that the pattern of this increase is suggestive of passive dilation in the early postoperative period, followed by normal active growth. (J Thorac Cardiovasc Surg 2000;119:4-9)
A lthough the majority of infants with severe aortic stenosis can receive palliation by commissurotomy or dilation procedures, a few require aortic valve replacement. In this the options are to use homografts or to perform an autotransplantation of the pulmonary valve into the aortic position (ie, the Ross operation). ${ }^{1}$ There is increasing evidence that homografts lack the potential of growth and become dysfunctional because of calcific degeneration. ${ }^{2-4}$ Pulmonary autografts, how-

From the Section of Paediatric Cardiology, Department of Paediatrics and Department of Thoracic Surgery, Sahlgrenska University Hospital, Göteborg, Sweden.

Supported by a grant from the Gothenburg Medical Society.

Received for publication March 31, 1999; revisions requested May 21, 1999; revisions received Aug 16, 1999; accepted for publication Sept 7, 1999.

Address for reprints: Laszlo Solymar, MD, PhD, Section of Paediatric Cardiology, Department of Paediatrics, Sahlgrenska University Hospital, S-416 85, Göteborg, Sweden (E-mail: laszlo.solymar@sahlgrenska.se).

Copyright $@ 2000$ by Mosby, Inc.

$0022-5223 / 2000 \$ 12.00+0 \quad \mathbf{1 2 / 1 / 1 0 3 0 2 2}$ ever, have the potential of maintained function and growth. Although previous studies in animals ${ }^{5,6}$ and human subjects ${ }^{7}$ have shown that the resected pulmonary valves can maintain viability, there is still limited knowledge about the long-term effects of the resection of the pulmonary root and its transfer into the aortic position, especially when performed in small children. The few reports published on the change in the size of the pulmonary autograft in children ${ }^{8-11}$ do not allow a distinction between passive dilation and active growth. We have performed the Ross procedure in selected infants since 1991, and because young infants are in the phase of very rapid somatic growth, they seem especially suitable for study to distinguish between growth and dilatation. We have also followed a group of healthy infants to assess the normal growth rate of the relevant aortic segments.

\section{Patients and methods}

Eight survivors of infantile aortic valve replacement with pulmonary autograft were enrolled into the study. Clinical and 


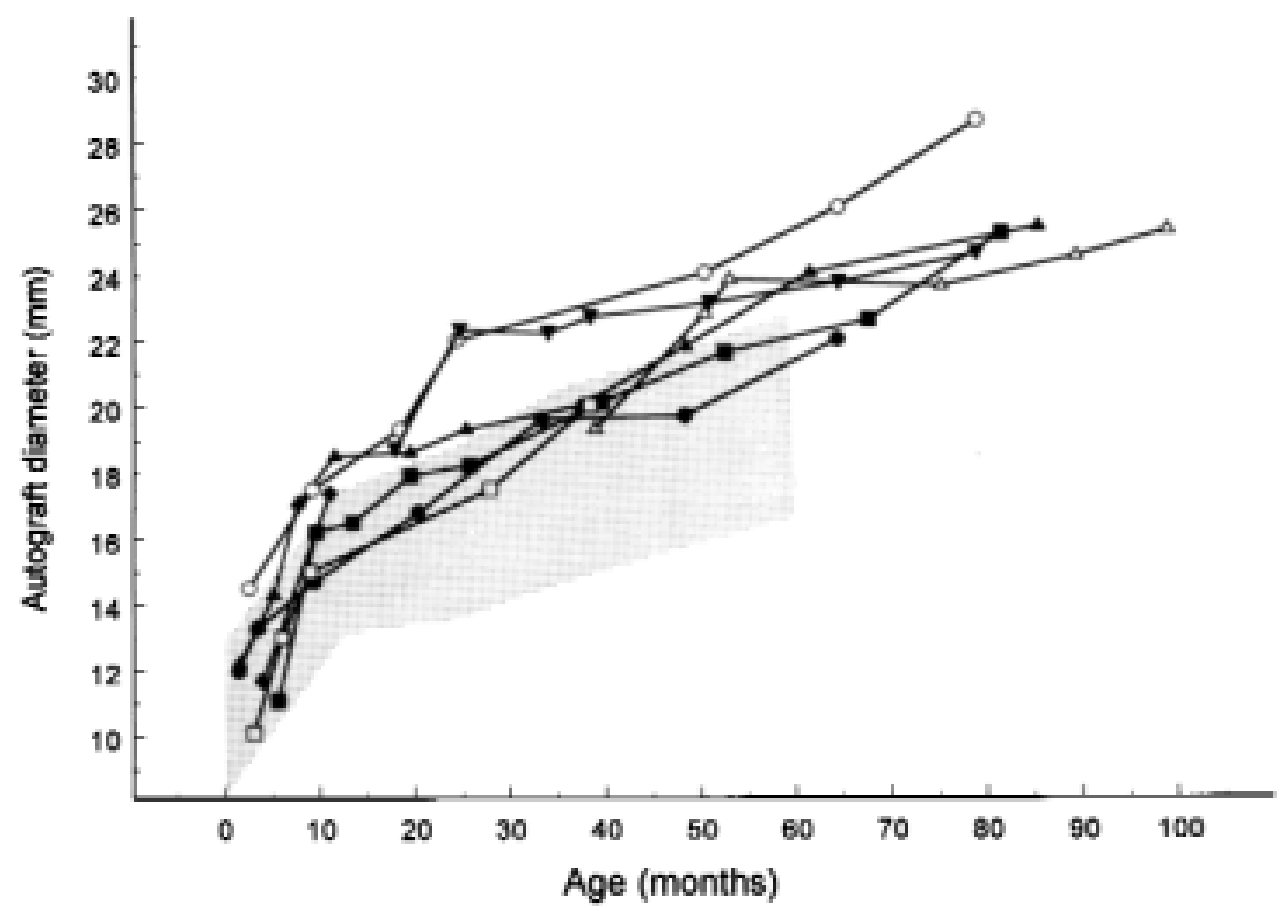

Fig 1. Individual measurement data on the proximal autograft diameters at surgery and during follow-up. The shaded area represents the $95 \%$ confidence intervals of the control group.

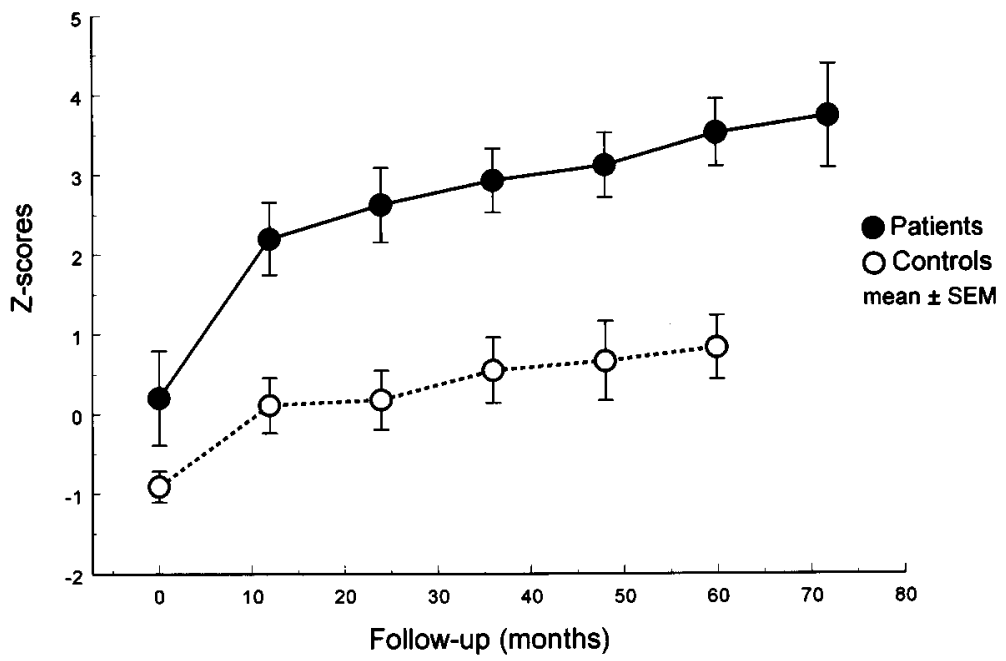

Fig 2. Time-related changes in the mean Z-values \pm SEM of the proximal autograft and the aortic root in patients and respective control subjects.

surgical data of 6 of these patients have been reported elsewhere. ${ }^{12}$ Of the 2 additional patients, 1 had a primary aortic valve replacement with a homograft that became severely stenotic and regurgitant, and the other was a prematurely born baby (birth weight, $1.5 \mathrm{~kg}$ ) who was treated with commissurotomy at the age of 1 month but continued to have significant stenosis and required repeated intervention. All patients were monitored with repeated echocardiographic studies, including 2-dimensional, Doppler, and color flow mapping. Echocardiograms were assessed for all subjects within 14 days of the operation and at 6 months, 12 months, and then yearly thereafter. Two to three measurements at the level of the sinus of Valsalva and at the distal anastomosis (sinoaortic junction) were obtained in systole and were 
Table I. Associated anomalies, previous palliations, and demographic and clinical data at the time of the Ross operation

\begin{tabular}{|c|c|c|c|}
\hline $\begin{array}{l}\text { Patiel } \\
\text { No. }\end{array}$ & $\operatorname{Sex}$ & Associated anomalies & Previous palliation \\
\hline 1 & $\mathrm{~F}$ & $\begin{array}{l}\text { Severe mitral regurgitation, } \\
\text { endocardial fibroelastosis }\end{array}$ & $\begin{array}{l}\text { 1. Transventricular dilation } \\
\text { 2. Transventricular dilation }\end{array}$ \\
\hline 2 & M & $\begin{array}{l}\text { Coarctation of the aorta, } \\
\text { endocardial fibroelastosis } \\
\text { PDA, ASD }\end{array}$ & $\begin{array}{l}\text { 1. Coarctation repair and transventricular dilation } \\
\text { 2. Commissurotomy }\end{array}$ \\
\hline 3 & $\mathrm{M}$ & Mitral regurgitation & Transventricular dilation \\
\hline 4 & M & $\begin{array}{l}\text { Hypertrophic obstructive } \\
\text { cardiomyopathy, PHT }\end{array}$ & $\begin{array}{l}\text { 1. Commissurotomy } \\
\text { 2. Balloon dilation }\end{array}$ \\
\hline 5 & M & None & Transventricular dilation \\
\hline 6 & M & None & $\begin{array}{l}\text { 1. Transventricular dilation } \\
\text { 2. Aortic homograft }\end{array}$ \\
\hline 7 & M & None & $\begin{array}{l}\text { 1. Subaortic resection } \\
\text { 2. Balloon dilation }\end{array}$ \\
\hline 8 & M & None & Transventricular dilation \\
\hline
\end{tabular}

$A V R$, Aortic valve replacement; $A S$, aortic stenosis; $P D A$, persistent ductus arteriosus; $A S D$, atrial septal defect; $P H T$, pulmonary hypertension.

Table II. Anatomic and hemodynamic data of the patients immediately after the Ross operation and at the last follow-up

\begin{tabular}{|c|c|c|c|c|c|c|c|c|c|c|}
\hline \multirow[b]{2}{*}{ Patient } & \multicolumn{5}{|c|}{ Immediately after surgery } & \multicolumn{5}{|c|}{ At the latest follow-up } \\
\hline & $\begin{array}{l}\text { Age } \\
\text { (mo) }\end{array}$ & $\begin{array}{l}B S A \\
\left(m^{2}\right)\end{array}$ & $\begin{array}{c}\text { Proximal } \\
\text { autograft } \\
(\mathrm{mm})\end{array}$ & $\begin{array}{c}\text { Distal } \\
\text { autograft } \\
(\mathrm{mm})\end{array}$ & $\begin{array}{c}\text { Aortic } \\
\text { regurgitation* }\end{array}$ & $\begin{array}{l}\text { Age } \\
(m o)\end{array}$ & $\begin{array}{l}B S A \\
\left(m^{2}\right)\end{array}$ & $\begin{array}{c}\text { Proximal } \\
\text { autograft } \\
(\mathrm{mm})\end{array}$ & $\begin{array}{c}\text { Distal } \\
\text { autograft } \\
(\mathrm{mm})\end{array}$ & $\begin{array}{c}\text { Aortic } \\
\text { regurgitation }\end{array}$ \\
\hline 1 & 1.5 & 0.21 & 12.2 & 10.3 & +1 & 85.5 & 0.79 & 25.4 & 15.6 & +1 \\
\hline 2 & 2.5 & 0.22 & 14.5 & 8.5 & 0 & 79 & 0.75 & 28.6 & 16.5 & 0 \\
\hline 3 & 5.6 & 0.29 & 11.1 & 10.1 & +1 & 81.6 & 1.06 & 25.2 & 15.8 & +1 \\
\hline 4 & 3.9 & 0.29 & 11.7 & 9.0 & 0 & 11 & 0.35 & 17.4 & 10.3 & 0 \\
\hline 5 & 18 & 0.48 & 18.7 & 14.6 & $0-+1$ & 79 & 0.78 & 24.6 & 19.5 & +1 \\
\hline 6 & 1.4 & 0.25 & 12.0 & 8.6 & 0 & 64.4 & 0.75 & 22 & 16.5 & 0 \\
\hline 7 & 39 & 0.61 & 19.3 & 12.7 & 0 & 99 & 0.96 & 25.3 & 18.6 & 0 \\
\hline 8 & 3.0 & 0.25 & 10.1 & 7.4 & 0 & 38.5 & 0.59 & 20 & 14 & +1 \\
\hline Mean & 9.4 & 0.33 & 13.7 & 10.2 & & 67.3 & 0.75 & 23.6 & 15.9 & \\
\hline SD & 12.3 & 0.14 & 3.28 & 2.25 & & 28 & 0.21 & 3.56 & 2.82 & \\
\hline
\end{tabular}

"Regurgitation validated by color Doppler area: 0 , none; $0-+1$, trivial; +1, mild; +2 , moderate; +3 , severe.

averaged. Preoperative pulmonary arterial pressure was assessed by cardiac catheterization in 2 patients and by echocardiography through the TR gradient in 5 patients. Demographic, anatomic, and clinical data at the time of surgery are given in Table I. The follow-up ranged from 0.5 to 7 years (median, 5.2 years). Because somatic growth could not be expected to be linear during follow-up, measurements were transformed to Z-values to normalize somatic growth, as suggested by Rimoldi and Lev. ${ }^{13}$ In the calculation of $\mathrm{Z}$ values, the data of Roman and colleagues ${ }^{14}$ were used as reference data. For comparison, 12 infants with diagnoses of insignificant muscular ventricular septal defects or physiologic murmurs were included as control subjects after institutional review board approval. Written consent was obtained for each patient. These control subjects were followed up from early infancy to school age (median, 4.9 years; range, 3.9 to 5.8 years), and repeated measurements of the aortic segments corresponding to those in the patient group were obtained at similar time intervals. As in our patients, Z-values were calculated by using the data of Roman and colleagues. ${ }^{14}$ Comparisons between patients and control subjects were made by using the unpaired $t$ test, and comparisons within each group, but at different ages, were made by using the paired $t$ test.

\section{Results}

There was 1 late death; patient 4 died at the age of 1 year of hypertrophic obstructive cardiomyopathy and severe pulmonary hypertension. All the others are 


\begin{tabular}{|c|c|c|c|c|}
\hline $\begin{array}{c}\text { Age at } \\
\text { previous palliation }(d)\end{array}$ & Indication for $A V R$ & $\begin{array}{c}\text { Age at } \\
\text { AVR (mo) }\end{array}$ & $\begin{array}{l}\text { Weight at } \\
\text { AVR }(\mathrm{kg})\end{array}$ & $\begin{array}{l}\text { Pulmonary } \\
\text { hypertension }\end{array}$ \\
\hline 1. $1,2.15$ & Congestive heart failure & 1.5 & 3.2 & Yes \\
\hline 1. $6,2.8$ & Congestive heart failure, residual AS & 1.7 & 3.5 & Yes \\
\hline 2 & Avulsion of the aortic valve, residual AS & 5.5 & 5.2 & No \\
\hline $1.3,2.66$ & Congestive heart failure, residual AS, angina & 4 & 5.4 & Yes \\
\hline 2 & Avulsion of the aortic valve, aortic regurgitation & 1.5 & 10.9 & No \\
\hline $1.3,2.35$ & Homograft stenosis and regurgitation & 17 & 4.6 & Yes \\
\hline 1. $60,2.270$ & Subvalvular aortic stenosis & 3 & 13.6 & Yes \\
\hline 10 & Residual aortic stenosis & 3 & 4.2 & No \\
\hline
\end{tabular}

Table III. Changes in the mean Z-score values during the first year and during further follow-up and comparison between patients and control subjects

\begin{tabular}{|c|c|c|c|c|c|c|c|c|c|c|}
\hline $\begin{array}{l}\text { Time } \\
\text { period (mo) }\end{array}$ & $n$ & $\begin{array}{l}\text { Proximal } \\
\text { autograft }\end{array}$ & $n$ & Aortic root & $\mathrm{P}$ value & $n$ & $\begin{array}{c}\text { Distal } \\
\text { autograft }\end{array}$ & $n$ & $\begin{array}{c}\text { Ascending } \\
\text { aorta }\end{array}$ & $\mathrm{P}$ value \\
\hline $0-12$ & 8 & $2.00(0.53)^{*}$ & 10 & $1.11(0.47)$ & .009 & 8 & $0.76(0.74)$ & 9 & $0.74(0.46)$ & .9 \\
\hline $12-60$ & 6 & $1.13(0.80)$ & 10 & $0.82(0.40)$ & .4 & 6 & $1.26(0.52)$ & 10 & $1.01(0.55)$ & 6 \\
\hline
\end{tabular}

*Values in brackets indicate SD.

symptom free and doing well, and the patient having previous repair of coarctation did not have any evidence of arch obstruction.

The substantial somatic growth of the patients during the follow-up period was reflected in a tripling of body weight, which increased from $6.3 \pm 3.8 \mathrm{~kg}$ to $18.7 \pm 7.3 \mathrm{~kg}$ (mean $\pm \mathrm{SD}$ ) and in a doubling of the body surface area, increasing from $0.32 \pm 0.14 \mathrm{~m}^{2}$ to $0.75 \pm 0.21 \mathrm{~m}^{2}$. During this period, the mean diameter of the proximal autograft increased from $13.7 \pm 3.5$ $\mathrm{mm}$ to $22.6 \pm 3.5 \mathrm{~mm}(P=.0001)$, and the distal anastomosis increased from $10.2 \pm 2.4 \mathrm{~mm}$ to $15.9 \pm 2.8$ $\mathrm{mm}(P=.001)$. Individual patient data are given in Table II, and individual measurements of autograft diameters with increasing age are shown in Fig 1. In most patients the proximal autograft diameter increases rapidly within the first year to reach and also exceed the upper range of the aortic root diameter of the control subjects. As previously pointed out, the use of Z-values allows assessment of growth pattern because increase related to somatic growth is included in each prediction. Fig 2 shows the development of the proximal autograft of the patients and the aortic root of the control subjects as group means of the Zvalues and bars of SEM. During the first postoperative year, the Z-value of the proximal autograft increased from $0.2 \pm 0.50$ to $2.2 \pm 0.38$, which significantly exceeded the first-year increase of the control subjects from $-0.9 \pm 0.12$ to $0.1 \pm 0.20(P=.01$, Table III $)$. During subsequent follow-up, both patients and control subjects had a slow progressive increase of the mean Z-values, but the difference between patients and control subjects was not statistically significant (Fig 2 and Table III).

The changes in the distal part of the autograft and corresponding measurements of the ascending aorta of the control subjects are shown in Fig 3. A progressive increase in the mean Z-values in both patients and control subjects can be seen, and there was no significant difference between the 2 groups at any time during follow-up (Table III).

\section{Discussion}

The Ross operation may be especially suited for small infants needing aortic valve replacements because mechanical valves are too bulky to be accom- 


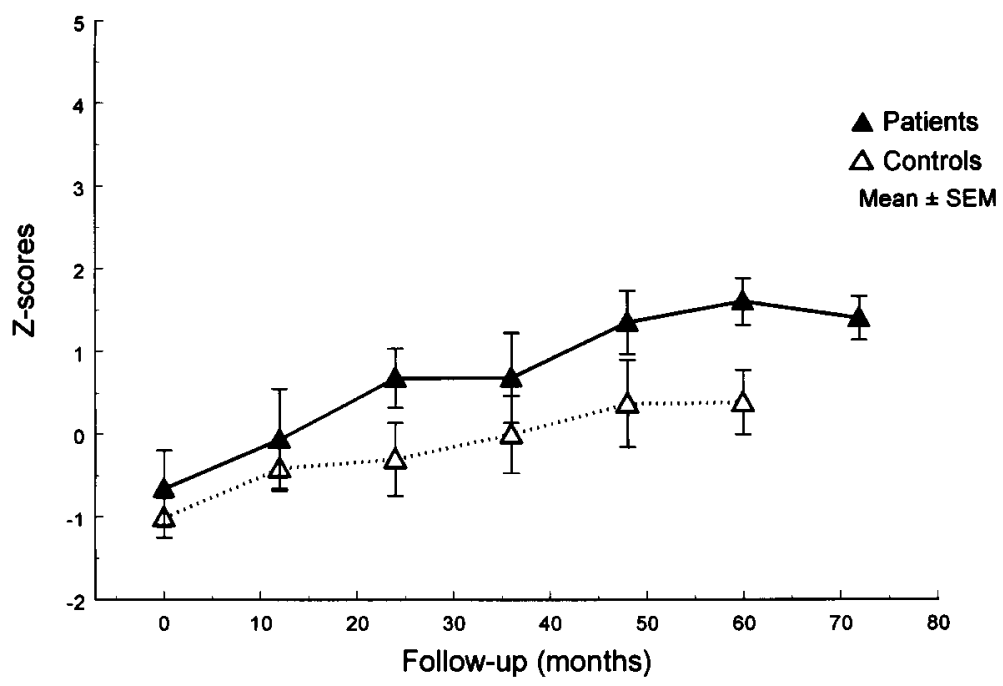

Fig 3. Time-related changes in the mean Z-values \pm SEM of the distal part of the autograft and the ascending aorta in patients and respective control subjects.

modated in the heart of the infant, and homografts in the systemic position have been found to malfunction early ${ }^{2-4}$ and seem to lack growth potential. ${ }^{15}$ The pulmonary autograft, being the patient's own tissue, is not subject to immunologic degenerative changes, but the surgical procedure involves transection of the vessels supplying the arterial wall, which may affect vessel wall mechanics and growth. In animal experiments such a transection was not found to prevent normal growth in isolated vessel segments ${ }^{6,16,17}$ or in valved segments. ${ }^{5,6}$ Explanted pulmonary autografts have also been found to have a viable vessel wall in human subjects $^{7}$ and thus a potential for growth in growing patients. Our study design aimed at assessing the growth pattern in a rapidly growing group of patients (ie, those undergoing the Ross procedure during early infancy). We could distinguish two patterns of diameter increase: one rapid one within the first year after surgery (most of which occurred in the first 6 months) and a slower one in the years thereafter. Several previous reports, with a fairly short follow-up, have shown a similar rapid increase in size soon after operation. ${ }^{8,10,11,18,19}$ Such a rapid increase in dimension is suggestive of passive dilation, and this mechanism is not surprising because the wall thickness and the number of elastic layers in the pulmonary artery are significantly smaller and less well organized than those of the aorta. ${ }^{20}$ In a recent animal study, Schoof and colleagues ${ }^{6}$ demonstrated a passive dilation of the pulmonary autograft, both valved and nonvalved, attributable to differences in vessel wall anatomy. In spite of this, in clinical experience progressive dilation leading to significant regurgitation has been seen only in a minority of cases with the pulmonary valve in the systemic position. ${ }^{7,21,22}$ Also in our study, aortic regurgitation was trivial or very mild directly after operation, and there was no evidence of significant progression during follow-up, despite the noted dilation. The maintained function may be attributed to the growth and remodeling of valve cusps, as found in the animal model,${ }^{6}$ withstanding a moderate dilation of the aortic sinus. Elkins and colleagues ${ }^{22}$ followed a large number of older children and showed that intra-aortic replacements tended to follow a normal diameter increase, whereas root replacements tended to dilate. All of our patients had aortic root replacement because they were small infants. Nevertheless, there was no clear evidence of progressive dilation after the first postoperative year, after which the growth pattern of the autograft was very similar to that seen in the control group and probably represents normal active growth. Although the Z-values continued to increase, even after the first year, this pattern was shared also by our control group and it seems probable that the predictions of Roman and colleagues ${ }^{14}$ are not fully representative of the very young subjects to which our study groups belong. The choice of Roman and colleagues as reference is justified by the similarity in study design and measurement sites and by the fact that corresponding reports containing data on aortic dimensions ${ }^{23,24}$ also showed similar underrepresentation of the very young. The reason that the distal autograft did not show dilata- 
tion similar to that of the proximal part is possibly due to the fact that the former was measured near the distal anastomosis. Suturing promotes fibrosis, which in turn could counteract passive dilation. The fate of the allograft in the pulmonic position is of concern and will require repeated operations in the future, even though the homografts in our small series continue to this time to perform well with only minor gradients, all below 30 $\mathrm{mm} \mathrm{Hg}$. This finding is in contrast to our experience with homografts in truncus arteriosus, in which increasing gradients and early dysfunction are frequently encountered. A tentative explanation for the maintained homograft function in the patients undergoing the Ross procedure may be the normal right ventricular outflow tract below the harvested pulmonary valve and subsequently below the homograft. Heinemann and colleagues ${ }^{15}$ showed that an absence of flow disturbances and gradients (even mild) improves the longevity of conduits.

In conclusion, we find that at midterm follow-up of the Ross operation in infancy, the pulmonary autograft shows evidence of normal growth after an initial passive dilation.

We thank Dr Thomas Gilljam for including one of his patients and medical student Endre Szarka for excellent assistance with data entry and calculation operations.

\section{REFERENCES}

1. Ross DN. Replacement of aortic and mitral valves with pulmonary autograft. Lancet 1967;2:956-8.

2. Clarke DR, Campel DN, Hayward AR, et al. Degeneration of aortic valve allografts in young recipients. J Thorac Cardiovasc Surg 1993;92:218-25.

3. Gallo R, Prabhakar G, Kumar N, et al. Accelerated degeneration of aortic homograft in an infant. J Thorac Cardiovasc Surg 1994; 107:1161-2.

4. Yankah AC, Alexi-Meskishvili V, Weng Y, et al. Accelerated degeneration of allografts in the first two years of life. Ann Thorac Surg 1995;60:S71-7.

5. Murata H. A study of autologous valve replantation. J Jpn Assoc Thorac Surg (Nippon Geka Gakkai Zasshi) 1984;32:144-8.

6. Schoof PH, Hazekamp MG, van Wermeskerken GK, et al. Disproportionate enlargement of the pulmonary autograft in the aortic position in the growing pig. J Thorac Cardiovasc Surg 1998;115:1264-72.

7. Matsuki O, Okita Y, Almeida RS, et al. Two decades' experience with aortic valve replacement with pulmonary autograft. J Thorac Cardiovasc Surg 1988;95:705-11.

8. Gerosa G, McKay R, Ross DN. Replacement of the aortic valve or root with a pulmonary autograft in children. Ann Thorac Surg 1991;51:424-9.

9. Elkins RC, Knott-Craig CJ, Ward KE, et al. Pulmonary autograft in children: realized growth potential. Ann Thorac Surg 1994; 57:1387-94.

10. Sievers HH, Leyh R, Loose R, et al. Time course dimension and function of the autograft pulmonary root in the aortic position. $\mathrm{J}$ Thorac Cardiovasc Surg 1993;105:775-80.

11. Schoof PH, Cromme-Dijkhuis AD, Bogers AJC, et al. Aortic root replacement with pulmonary autograft in children. $\mathrm{J}$ Thorac Cardiovasc Surg 1994;107:367-73.

12. Südow G, Solymar L, Eriksson B, et al. Aortic valve replacement with a pulmonary autograft in infants with critical aortic stenosis. J Thorac Cardiovasc Surg 1996;112:433-6.

13. Rimoldi HJA, Lev M. A note on the concept of normality and abnormality in quantitation of pathologic findings in congenital heart disease. Pediatr Clin North Am 1963;10:589-91.

14. Roman MJ, Devereux RB, Kramer-Fox R, O'Laughlin J. Twodimensional echocardiographic aortic root dimensions in normal children and adults. Am J Cardiol 1989;64:507-12.

15. Heinemann MK, Hanley FL, Fenton KN, et al. Fate of small aortic homograft conduits after early repair of truncus arteriosus. Ann Thorac Surg 1993;55:1409-12.

16. Kreitmann B, Riberi A, Jimeno M-T, Metras D. Experimental basis for autograft growth and viability. J Heart Valve Dis 1995; 4:379-83.

17. Sawatari K, Kawata H, Armiger LC, Jonas RA. Growth of composite conduits utilising longitudinal arterial autograft in growing lambs. J Thorac Cardiovasc Surg 1992;103:47-51.

18. Calhoon JH, Bolton JW. Ross/Konno procedure for critical aortic stenosis in infancy. Ann Thorac Surg 1995;60:S597-9.

19. Reddy VM, Rajasinghe HA, McElhinney, et al. Extending the limits of the Ross procedure. Ann Thorac Surg 1995;60:S600-3.

20. Plank L, James J, Wagenvoort CA. Caliber and elastin content of the pulmonary trunc. Arch Pathol Exp Med 1979;104:238-45.

21. Schmid FK, Hilker M, Kampman C, et al. Clinical performance of native pulmonary valve in the systemic circulation. J Heart Valve Dis 1998;7:620-5.

22. Elkins RC, Knott-Craig CJ, Ward KE, Lane MM. The Ross operation in children: 10-years experience. Ann Thorac Surg 1998; 65:496-502.

23. Snider AR, Enderlein MA, Teitel DF, Juster RP. Two-dimensional echocardiographic determination of aortic and pulmonary artery sizes from infancy to adulthood in normal subjects. Am J Cardiol 1984;53:218-24.

24. Ichida F, Aubert A, Denef B, Dumoulin M, van der Hauvert LG. Cross sectional echocardiographic assessment of the great artery diameters in infants and children. Br Heart J 1987;58:627-34. 